\title{
Effect of Hydrophobic and Hydrophilic Metal Oxide Nanoparticles on the Performance of Xanthan Gum Solutions for Heavy Oil Recovery
}

\author{
Laura M. Corredor ${ }^{\circledR}$, Maen M. Husein * and Brij B. Maini * \\ Department of Chemical and Petroleum Engineering, University of Calgary, Calgary, AB T2N 1N4, Canada; \\ laura.corredor@ucalgary.ca \\ * Correspondence: mhusein@ucalgary.ca (M.M.H.); bmaini@ucalgary.ca (B.B.M.)
}

Received: 21 November 2018; Accepted: 7 January 2019; Published: 12 January 2019

\begin{abstract}
Recent studies revealed higher polymer flooding performance upon adding metal oxide nanoparticles (NPs) to acrylamide-based polymers during heavy oil recovery. The current study considers the effect of $\mathrm{TiO}_{2}, \mathrm{Al}_{2} \mathrm{O}_{3}$, in-situ prepared $\mathrm{Fe}(\mathrm{OH})_{3}$ and surface-modified $\mathrm{SiO}_{2} \mathrm{NPs}_{\text {s }}$ on the performance of xanthan gum (XG) solutions to enhance heavy oil recovery. Surface modification of the $\mathrm{SiO}_{2} \mathrm{NPs}$ was achieved by chemical grafting with 3-(methacryloyloxy)propyl]trimethoxysilane (MPS) and octyltriethoxysilane (OTES). The nanopolymer sols were characterized by their rheological properties and $\zeta$-potential measurements. The efficiency of the nanopolymer sols in displacing oil was assessed using a linear sand-pack at $25{ }^{\circ} \mathrm{C}$ and two salinities $(0.3 \mathrm{wt} \%$ and $1.0 \mathrm{wt} \% \mathrm{NaCl})$. The $\zeta$-potential measurements showed that the NP dispersions in deionized (DI) water are unstable, but their colloidal stability improved in presence of XG. The addition of unmodified and modified $\mathrm{SiO}_{2} \mathrm{NPs}$ increased the viscosity of the $X G$ solution at all salinities. However, the high $X G$ adsorption onto the surface of $\mathrm{Fe}(\mathrm{OH})_{3}, \mathrm{Al}_{2} \mathrm{O}_{3}$, and $\mathrm{TiO}_{2} \mathrm{NPs}$ reduced the viscosity of the XG solution. Also, the NPs increased the cumulative oil recovery between $3 \%$ and $9 \%$, and between $1 \%$ and $5 \%$ at $0 \mathrm{wt} \%$ and $0.3 \mathrm{wt} \% \mathrm{NaCl}$, respectively. At $1.0 \mathrm{wt} \% \mathrm{NaCl}$, the NPs reduced oil recovery by XG solution between $5 \%$ and $12 \%$, except for $\mathrm{Fe}(\mathrm{OH})_{3}$ and $\mathrm{TiO}_{2}$ NPs. These NPs increased the oil recovery between $2 \%$ and $3 \%$ by virtue of reduced polymer adsorption caused by the alkalinity of the $\mathrm{Fe}(\mathrm{OH})_{3}$ and $\mathrm{TiO}_{2}$ nanopolymer sols.
\end{abstract}

Keywords: nanoparticle; metal oxide; polymer flooding; xanthan gum; heavy oil

\section{Introduction}

Water-soluble polymers have been used in enhanced oil recovery (EOR) due to their ability to improve sweep efficiency by controlling water mobility, reducing water permeability in swept zones and contacting unswept zones of the reservoir [1]. Hydrolyzed polyacrylamide (HPAM) and xanthan gum are the most commonly used polymers for EOR [2]. Xanthan gum (XG) is a high molecular anionic polysaccharide produced by bacterium Xanthomonas campestris during the fermentation of a cellulosic backbone [3]. XG solution properties have been studied over the past 50 years. The main topics of interest include rheological behavior of XG solutions and their mixtures with other polymers [4-9], effect of temperature on polymer conformation [10-12], and effect of salinity on solution performance and polymer conformation $[13,14]$.

In solution, XG exhibits two conformational states: an ordered helix conformation and a disordered coil conformation [13]. The conformation of the XG molecules depends on the ionic strength of the solution and the temperature. In the presence of salts, XG molecules adopt a rigid rod like structure (ordered conformation) because the negatively charged pyruvate molecules wrap 
around the backbone of the polymer [3,15]. In salt-free solutions, XG molecules have a highly extended and disordered conformation due to the electrostatic repulsion between their charged side chains and their backbone. At low temperatures, XG molecules adopt the helix structure, which converts to a disordered coil at high temperatures [3]. The temperature limit for XG was suggested to be between $70{ }^{\circ} \mathrm{C}$ and $90^{\circ} \mathrm{C}$ by Wellington [16], Ryles [17], and Seright and Henrici [18]. These reports showed that XG solutions are thermally stable at salt concentrations where XG chains remained in an ordered structure.

At low concentrations, $\mathrm{XG}$ has been used as a stabilizer of NPs in aqueous solutions for thermal recovery of heavy oil [19] and for drilling fluids [20,21]. Other works include the study of the effect of NPs on the rheological behavior of XG solutions [22-25]. However, the role of NPs in modifying the polymer performance for oil recovery has not been widely studied. Recently reported studies have shown that the addition of silica NPs to polyacrylamide solutions increases their mobility control ability, temperature tolerance, and salt-tolerance [26-35] and, consequently, increases the oil recovery.

Saha and coworkers [36] investigated the effect of hydrophilic silica NPs on the stability of crude oil-XG emulsions. They reported that the addition of the silica NPs improved the stability of the emulsions at all polymer concentrations investigated (1000-5000 ppm). Nevertheless, higher emulsification and better stability periods were obtained at $5000 \mathrm{ppm}$ of XG and $0.3 \mathrm{wt} \%$ of silica NPs. The higher emulsification was attributed to the adsorption of the NPs at the oil-water interface, which reduced the interfacial tension (IFT) and the oil droplet sizes and size distribution. Moreover, the NPs changed the wettability of the system from intermediately oil-wet to water-wet, improving the oil recovery between $18 \%$ and $20 \%$ at 30 and $80{ }^{\circ} \mathrm{C}$, respectively.

Nanosilica particles have been the most-studied NPs for both nanoflooding and nanopolymer flooding processes. Other NPs, such as $\mathrm{TiO}_{2}$ and $\mathrm{Al}_{2} \mathrm{O}_{3}$, in aqueous solutions, have shown great potential to enhance oil recovery for both light and heavy oil [37-40]. To the best of the authors' knowledge, there are no literature investigations on the effect of the addition of $\mathrm{Fe}(\mathrm{OH})_{3}, \mathrm{TiO}_{2}$, and $\mathrm{Al}_{2} \mathrm{O}_{3}$ NPs to $X G$ solutions as a secondary recovery method. The primary objective of this study is to examine the feasibility of improving the performance of $X G$ polymer flood through adding $\mathrm{TiO}_{2}$, $\mathrm{Al}_{2} \mathrm{O}_{3}$, in situ $\mathrm{Fe}(\mathrm{OH})_{3}$, and surface-modified $\mathrm{SiO}_{2} \mathrm{NPs}$. Silica functionalization may increase the hydrophobicity of the NPs and, hence, enhance their dispersivity into the polymer solution. Silica functionalization may also tailor the interaction between the treated NPs and the polymer to improve the mobility control ability of the polymer solution and, consequently, increase the oil recovery.

\section{Materials and Methods}

\subsection{Materials}

The nanoparticles used in this study were fumed silica $(99.5 \%, 7 \mathrm{~nm})$, aluminum oxide $(99.8 \%$, $13 \mathrm{~nm}$ ) (from Sigma-Aldrich, St. Louis, MO, USA), titanium dioxide (99.5\%, between 10-30 nm) (from Skyspring nanomaterials, Houston, TX, USA), and in situ-prepared $\mathrm{Fe}(\mathrm{OH})_{3} \mathrm{NPs}$. Ferric chloride hexahydrate $\left(\mathrm{FeCl}_{3} \cdot 6 \mathrm{H}_{2} \mathrm{O}, 98 \%\right.$ ) and sodium hydroxide, $5 \mathrm{M}$ (From Sigma-Aldrich, St. Louis, $\mathrm{MO}$, USA) were used to prepare the $\mathrm{Fe}(\mathrm{OH})_{3} \mathrm{NPs}$ in situ. The silica NPs were modified with two silanes, triethoxy(octyl)silane (OTES, >97.5\%) and 3-(methacryloyloxy)propyl]trimethoxysilane (MPS, 98\%) (from Sigma-Aldrich, St. Louis, MO, USA). The solvents used for silica NP modification were ethanol (EtOH, 99\%) and cyclohexane (99.5\%) (from Fisher Scientific, Bartlesville, OK, USA). Xanthan gum (XG, MW $>2 \times 10^{6} \mathrm{Da}$ ) was supplied by MP Biomedicals (Santa Ana, CA, USA). Sodium dodecyl sulfate (SDS, $\geq 98.5 \%$ ) (from Sigma-Aldrich, St. Louis, MO, USA) was the surfactant used in nanopolymer sol preparation, and formaldehyde solution (37 wt $\%$ in water, containing $10 \%-15 \%$ of methanol as a stabilizer) (from Sigma-Aldrich, St. Louis, MO, USA) was used as a biocide. The displacement tests were performed with silicon oil $(2400 \mathrm{cP})$ supplied by Nye lubricants (Fairhaven, MA, USA). Brine was prepared using sodium chloride $(\mathrm{NaCl}, 99 \%)$. The silica sand (100-140 mesh) used for the displacement tests was supplied by AGSCO (Wheeling, IL, USA). 


\section{2. $\mathrm{SiO}_{2} \mathrm{NP}$ Surface Modification}

A mass of $4 \mathrm{~g}$ of $\mathrm{SiO}_{2} \mathrm{NPs}$ dispersed into $80 \mathrm{~mL}$ of cyclohexane were mixed with $1.6 \mathrm{~mL}$ of MPS or $2.09 \mathrm{~mL}$ of OTES. The dispersion was stirred at $200 \mathrm{rpm}$ for $12 \mathrm{~h}$ at room temperature for the reaction to take place. After treatment, the product was recovered by centrifugation at $2500 \mathrm{rpm}$ for $30 \mathrm{~min}$ and washed three times with ethanol to remove the excess modifier. The precipitate was dried in an oven at $70{ }^{\circ} \mathrm{C}$ for $24 \mathrm{~h}$. Masses of $3.44 \mathrm{~g}$ of $\mathrm{SiO}_{2}$-MPS and $3.29 \mathrm{~g}$ of $\mathrm{SiO}_{2}$-OTES NPs were recovered, since some NPs were lost during preparation.

\subsection{Modified NP Characterization}

Fourier-transform infrared (FTIR) spectra were recorded over the range of $4000-400 \mathrm{~cm}^{-1}$ in a FTIR spectrometer (model IRaffinity-1s, Shimadzu, Japan) using $\mathrm{KBr}$ for running the background spectrum. Thermogravimetric analysis (TGA), from 20 to $800{ }^{\circ} \mathrm{C}$, were performed on Q600 TGA (TA instruments, Inc., New Castle, DE, USA) at a heating rate of $10^{\circ} \mathrm{C} / \mathrm{min}$ in air atmosphere.

\subsection{Nanopolymer Sol Preparation}

The NPs were first dispersed in DI water at $0.2 \mathrm{wt} \%$ and ultrasonicated for $1 \mathrm{~h}$. SDS was added at $0.1 \mathrm{wt} \%$, and the dispersions were stirred for $30 \mathrm{~min}$. Then, XG at $0.4 \mathrm{wt} \%$ was added and stirred for $1 \mathrm{~h}$. Finally, $\mathrm{NaCl}$ was added to the sample to achieve a concentration of $0.3 \mathrm{wt} \%$ or $1.0 \mathrm{wt} \%$.

For the preparation of the nanopolymer sols with in situ $\mathrm{Fe}(\mathrm{OH})_{3} \mathrm{NPs}, 0.2 \mathrm{~g}$ of the polymer and $0.05 \mathrm{~g}$ of SDS were dissolved into $35 \mathrm{~mL}$ of DI water. Then, $1.02 \mathrm{~g}$ of an aqueous solution of $\mathrm{FeCl}_{3} \cdot 6 \mathrm{H}_{2} \mathrm{O}$ (19.98 $\mathrm{g}$ of $\mathrm{FeCl}_{3} \cdot 6 \mathrm{H}_{2} \mathrm{O}$ in $25 \mathrm{~mL}$ of DI water) and $1.86 \mathrm{~g}$ of an aqueous solution of $\mathrm{NaOH}(5 \mathrm{~N})$ were added to the solution. The sample was left to mix at $150 \mathrm{rpm}$ at $25^{\circ} \mathrm{C}$ for $10 \mathrm{~min}$. Then, $12.69 \mathrm{~g}$ of DI water were added. The reaction produces $0.3 \mathrm{wt} \%$ of $\mathrm{NaCl}$, as a byproduct, according to the following reaction:

$$
\mathrm{FeCl}_{3(s)}+3 \mathrm{NaOH}_{(a q)} \rightarrow \mathrm{Fe}(\mathrm{OH})_{3(s)}+3 \mathrm{NaCl}_{(a q)} .
$$

\subsection{Colloidal Stability and Particle Size}

$\zeta$-potential values of each nanopolymer sol were measured at $20^{\circ} \mathrm{C}$ in absence of $\mathrm{NaCl}$ using a Zetasizer Nano ZS unit (Malvern Instruments Ltd., Malvern, UK), with uncertainty in the order of $\pm 1 \%$ to $\pm 6 \%$ of the reported value. The measurements were conducted after ultrasonicating each sample for $5 \mathrm{~min}$. The $\zeta$-potential values were measured at $0.2 \mathrm{wt} \% \mathrm{NaCl}$. These values could not be measured at higher ionic strength $(0.3 \mathrm{wt} \%$ and $1.0 \mathrm{wt} \% \mathrm{NaCl})$ due to the high conductivity values $(>5 \mathrm{mS} / \mathrm{cm})$. Particle size measurements were carried out by dynamic light scattering (DLS) using a particle size analyzer (Zetasizer nano ZS) at $20{ }^{\circ} \mathrm{C}$. The results are presented in Table S1 of the supplementary material. A digital pH meter (Fisher Scientific, model AB 15 plus, Santa Barbara, CA, USA) with an uncertainty of less than \pm 0.05 of the reported value was used to measure the $\mathrm{pH}$ values at $20^{\circ} \mathrm{C}$.

\subsection{Viscosity of the Nanopolymer Sols}

The viscosities of the nanopolymer sols were measured at $25{ }^{\circ} \mathrm{C}$ using a viscometer (Thermo Scientific ${ }^{\mathrm{TM}}$ HAAKE RotoVisco 1, Santa Barbara, CA, USA). The uncertainty of the reported valued remained between $\pm 1 \%$ to $\pm 7 \%$. The shear rate was varied from 5.0 to $100 \mathrm{~s}^{-1}$.

\subsection{Displacement Test in Linear Sand-Pack}

A stainless-steel tube with $30.4 \mathrm{~cm}$ length and $2.54 \mathrm{~cm}$ i.d. was used as a holder for silica sand. The packing process was carried out by filling the holder with sand and frequently tapping it to ensure the sand was tightly packed. The volume of the sand grains was determined as the weight of the sand into the holder divided by the density of the grains $\left(2.6 \mathrm{~g} / \mathrm{cm}^{3}\right)$. The pore volume (PV) of the porous media was calculated by subtracting the volume of sand grains in the holder from the total volume of the holder $\left(154.4 \mathrm{~cm}^{3}\right)$. Porosity was calculated as pore volume divided by total volume of the holder. 
For the displacement tests, the sand-pack is initially fully saturated with brine by evacuating the pore space with a vacuum pump and allowing the DI water to imbibe under high vacuum. In order to determine the permeability of the porous media $\left(K_{a b s}\right)$ from Equation (1), DI water was injected at different flow rates $(10,20,30$, and $40 \mathrm{~mL} / \mathrm{min})$, and the corresponding pressure drop was recorded.

$$
K_{a b s}=\frac{L}{A} \cdot \mu \cdot Q \cdot \frac{1}{\Delta P}
$$

where $L$ is the length of the pack, $\mathrm{cm} ; A$ is the cross-sectional area of the pack, $\mathrm{cm}^{2} ; \mu$ is the viscosity of the fluid, mPa.s; $Q$ is the flow rate, $\mathrm{cm}^{3} / \mathrm{s}$; and $\Delta P$ is the differential pressure across the sand-pack, atm.

The drainage process was carried out by injecting 2 pore volumes (PV) of silicon oil at $0.1 \mathrm{~mL} / \mathrm{min}$ until the water fraction at the production end was less than $1 \%$, and the pressure stabilized. The initial oil saturation was calculated by dividing the volume of produced water during oil flooding by the pore volume. After that, 1 PV of polymer solution or nanopolymer sol was injected followed by 2 PV of water. Cumulative oil recovery was calculated by dividing the sum of oil recovered from the chemical flood by the initial volume of oil in the sand-pack. The aqueous and oil phases were separated by heating the collected samples at $70^{\circ} \mathrm{C}$ for $30 \mathrm{~min}$ in an oven.

\section{Results and Discussion}

\subsection{FTIR and TGA Measurements of the Modified Silica NPS}

The FTIR spectra of unmodified and modified silica NPs after normalization of the peak area are shown in Figure 1. The asymmetric and symmetric stretching vibrations of $\mathrm{C}-\mathrm{H}$ groups of MPS for the $\mathrm{SiO}_{2}$-MPS NPs were clearly observed around 2951 and $2481 \mathrm{~cm}^{-1}$, and the stretching vibration of $\mathrm{C}=\mathrm{O}$, methylene $\left(=\mathrm{CH}_{2}\right)$, and vinyl $\left(-\mathrm{CH}=\mathrm{CH}_{2}\right)$ bending vibrations were observed at 1703,1456 , and $1406 \mathrm{~cm}^{-1}$ [41], respectively. For $\mathrm{SiO}_{2}$-OTES NPs, two peaks appear at $2926 \mathrm{~cm}^{-1}$ and $2858 \mathrm{~cm}^{-1}$ due to the intense symmetric and asymmetric stretching vibrations of the $\mathrm{C}-\mathrm{H}$ bonds in the octyl groups [42]. A peak also appears at $1392 \mathrm{~cm}^{-1}$, which is assigned to the asymmetric deformation vibration of $\mathrm{C}-\mathrm{H}$ bonds due to a slight substitution of the octyl groups in place of the $-\mathrm{OH}$ groups of the $\mathrm{SiO}_{2}$ NPs [43].
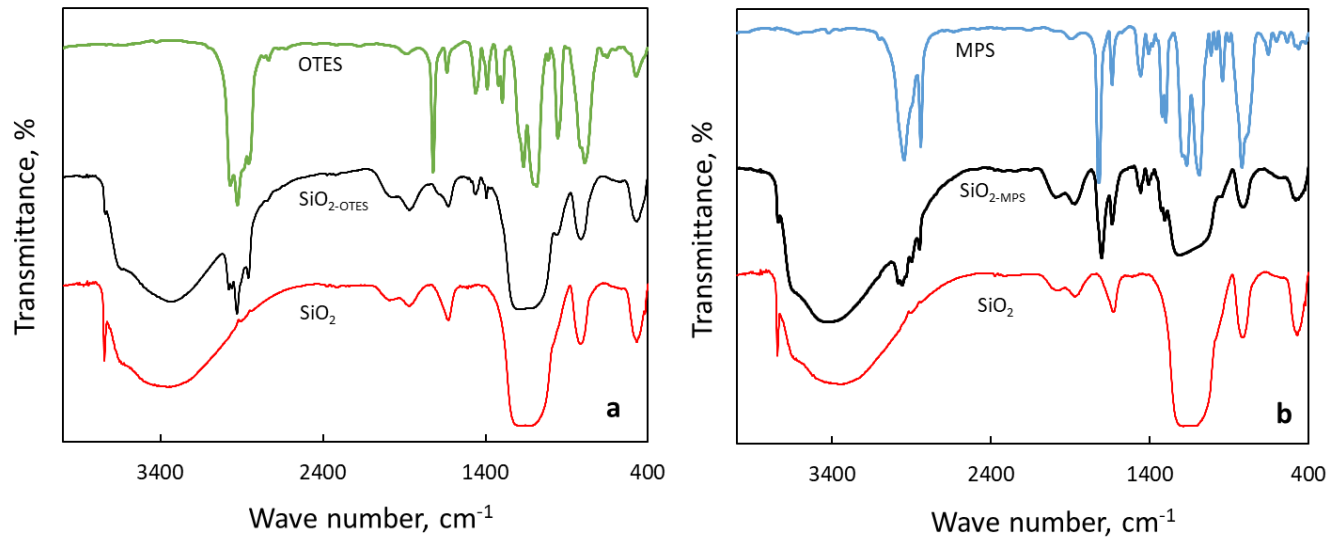

Figure 1. IR spectra of (a) $\mathrm{SiO}_{2}, \mathrm{SiO}_{2}$-OTES, and OTES, and (b) $\mathrm{SiO}_{2}-\mathrm{MPS}$ and MPS.

The TGA thermograms shown in Figure 2 correspond to the unmodified and modified silica NPs. The thermogram of unmodified $\mathrm{SiO}_{2}$ NPs shows the desorption of physisorbed water up to $400{ }^{\circ} \mathrm{C}$ and the dehydroxylation of adjacent - $\mathrm{OH}$ groups between 400 and $800{ }^{\circ} \mathrm{C}$ [44]. The weight losses of each region were $25.71 \%$ and $6 \%$, respectively. For modified silica NPs, the weight losses detected up to $100{ }^{\circ} \mathrm{C}$ were attributed to volatile solvents and unbound water. The weight loss for $\mathrm{SiO}_{2}-\mathrm{OTES}$ and $\mathrm{SiO}_{2}-\mathrm{MPS}$ in this region were $13.37 \%$ and $15.37 \%$, respectively. The onset of oxidation of $\mathrm{SiO}_{2}-\mathrm{OTES}$ 
and $\mathrm{SiO}_{2}$-MPS was found at $200{ }^{\circ} \mathrm{C}$. Temperatures for maximum oxidation were $245^{\circ} \mathrm{C}$ for $\mathrm{SiO}_{2}-\mathrm{OTES}$, and $300{ }^{\circ} \mathrm{C}$ for $\mathrm{SiO}_{2} \mathrm{MPS}$, and the weight loss was $15.48 \%$ and $23.41 \%$, respectively.

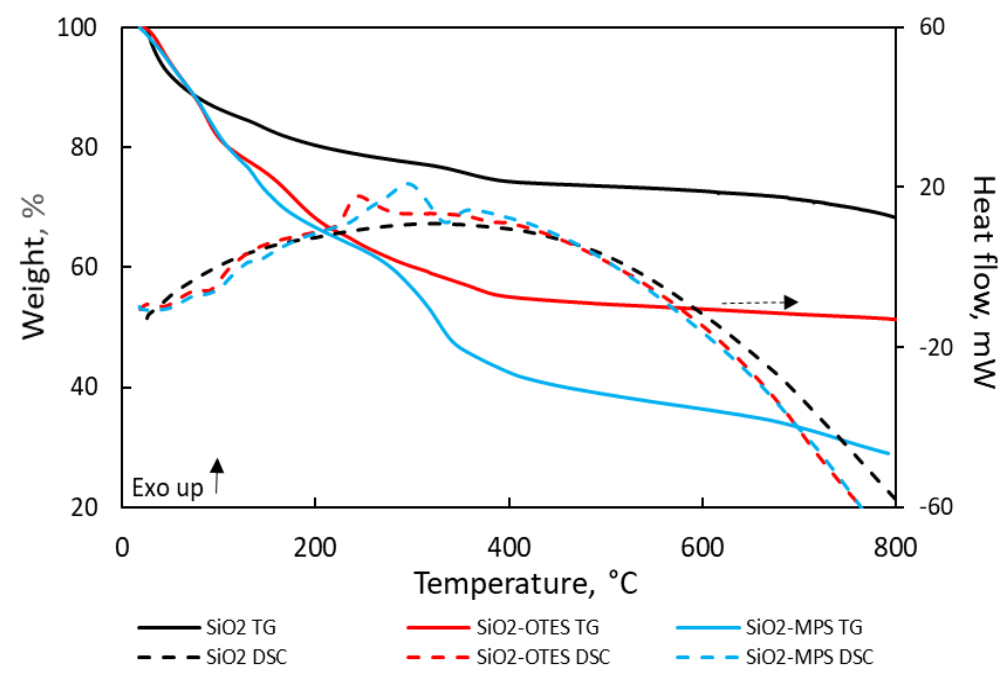

Figure 2. TG/DSC curves of $\mathrm{SiO}_{2}-\mathrm{MPS}$ and $\mathrm{SiO}_{2}$-OTES under air atmosphere.

\subsection{Colloidal Stability}

The colloidal stability of NP dispersions can be predicted by the magnitude of the $\zeta$-potential. Dispersions with $\zeta$-potential values greater than $+30 \mathrm{mV}$ or less than $-30 \mathrm{mV}$ typically have a high degree of stability [45]. NP dispersions with a low $\zeta$-potential value will eventually agglomerate under the effect of interparticle attractions. Accordingly, most of the nanofluids (NPs dispersed in DI water) should potentially be unstable, as reported in Table 1. The mechanisms causing the instability of these NPs can be hydrophobic interactions among the modified silica NPs, or the hydrogen bonding between the silanols groups of the unmodified NPs.

It was observed that the unmodified silica nanofluid was stable despite its low $\zeta$-potential value. The same observation was reported by Gun'ko et al. [46]. They suggest that the hydration layer formed between the silanols groups on the silica surface, and the water molecules through hydrogen bonding, prevent the agglomeration of the NPs. Effective steric hindrance leads to net repulsive interparticle forces despite the lack of charges on the silica surface [47]. The hydration effect was, nevertheless, not observed in the other hydrophilic NPs (i.e., $\mathrm{Al}_{2} \mathrm{O}_{3}, \mathrm{TiO}_{2}$, and $\mathrm{Fe}(\mathrm{OH})_{3}$ ). TGA analysis showed that the weight loss associated with the desorption of physisorbed water (up to $400{ }^{\circ} \mathrm{C}$ ) for unmodified $\mathrm{SiO}_{2}$ NPs was 25.71\%, while the weight losses for $\mathrm{Al}_{2} \mathrm{O}_{3}, \mathrm{TiO}_{2}$, and $\mathrm{Fe}(\mathrm{OH})_{3}$ were $0.49 \%, 3.78 \%$, and $5 \%$, respectively. The instability of $\mathrm{Al}_{2} \mathrm{O}_{3}$ and $\mathrm{TiO}_{2}$ in water was previously reported by Hendraningrat and Torsæter [38].

The $\zeta$-potential for $\mathrm{Al}_{2} \mathrm{O}_{3} \mathrm{NPs}$ in DI water is $+16.4 \mathrm{mV}$ at $\mathrm{pH} 6.75$, which is relatively high, consistent with the fact that this $\mathrm{pH}$ is far from their isoelectric point ( $\mathrm{pH}$ IEP $=9.1$ ) [48]. When alumina is dispersed in water, it behaves like a basic oxide which consumes $\mathrm{H}^{+}$ions. Thus, it possessed positive surface charges [48]. Upon adding SDS, the potential changes sign $(-26.9 \mathrm{mV})$, which could be explained by the adsorption of SDS onto the surface of the positively charged NPs as a bilayer, with the sulfate headgroups exposed to the solution [49]. Formation of a surfactant bilayer with concomitant charge reversal of the alumina particles with anionic sodium dodecyl sulfonate surfactant was previously reported by Somasundaran and Fuerstenau [50]. In general, the addition of SDS increased the negative magnitude of the $\zeta$-potential values of the NPs, but did not improve their stability.

The nanopolymer sols prepared in this study are stable (Table 1), mainly because of the stabilizing effect of the adsorbed polymeric chains onto the NPs surface inducing steric repulsion. In addition, the stability of the suspension increased due to the increase in the viscosity of the dispersion medium [51]. 
In general, polymer adsorption results from electrostatic and non-electrostatic interactions and the balance between these forces. The adsorption of XG chains onto the surface of the unmodified $\mathrm{SiO}_{2}$, $\mathrm{Fe}(\mathrm{OH})_{3}$, and $\mathrm{TiO}_{2} \mathrm{NPs}$ likely occurs through hydrogen bonding between -OH groups on the surface of the NPs and the carboxylic groups on the side chains of the XG, and on the positively charged $\mathrm{Al}_{2} \mathrm{O}_{3} \mathrm{NPs}$ through electrostatic attraction forces. The adsorption onto the modified $\mathrm{SiO}_{2}-\mathrm{MPS}$ and $\mathrm{SiO}_{2}$-OTES NPs likely occurs through hydrophobic interactions between the polymer backbone and the $\mathrm{R}-\mathrm{CH}_{3}$ chain of the modifiers on the silica surface. It was observed that the addition of $0.2 \mathrm{wt} \%$ $\mathrm{NaCl}$ to the nanopolymer sols reduced their $\zeta$-potential values, but did not destabilize them.

Table 1. $\zeta$-potential and $\mathrm{pH}$ values of xanthan gum (XG) nanopolymer sols at $20^{\circ} \mathrm{C}$.

\begin{tabular}{|c|c|c|c|c|c|c|c|}
\hline \multirow[b]{3}{*}{ NP Type } & \multirow[b]{3}{*}{ Dispersion Medium } & \multicolumn{6}{|c|}{$\mathrm{NaCl}$ Concentration, wt \% } \\
\hline & & \multicolumn{2}{|c|}{0} & \multicolumn{2}{|c|}{0.2} & \multirow{2}{*}{$\begin{array}{l}0.3 \\
\mathrm{pH}\end{array}$} & \multirow{2}{*}{$\begin{array}{c}1 \\
\mathrm{pH}\end{array}$} \\
\hline & & $\zeta$-Potential & $\mathrm{pH}$ & $\zeta$-Potential & $\mathrm{pH}$ & & \\
\hline \multirow{3}{*}{$\mathrm{SiO}_{2}$} & DI water & -17.5 & 6.89 & - & - & - & - \\
\hline & DI water-SDS & -25.1 & 6.73 & - & - & - & - \\
\hline & XG-SDS & -65.7 & 6.62 & -56.3 & 6.44 & 6.73 & 6.89 \\
\hline \multirow[t]{3}{*}{$\mathrm{SiO}_{2}$-OTES } & DI water & -20.7 & 7.01 & - & - & - & - \\
\hline & DI water-SDS & -28.3 & 6.89 & - & - & - & - \\
\hline & XG-SDS & -65.9 & 6.55 & -57.8 & 6.38 & 6.60 & 6.75 \\
\hline \multirow[t]{3}{*}{$\mathrm{SiO}_{2}$-MPS } & DI water & -20.3 & 7.06 & - & - & - & - \\
\hline & DI water-SDS & -29.4 & 6.77 & - & - & - & - \\
\hline & XG-SDS & -65.7 & 6.35 & -59.1 & 6.22 & 6.61 & 6.85 \\
\hline \multirow[t]{3}{*}{$\mathrm{TiO}_{2}$} & DI water & -25.3 & 6.95 & - & - & - & - \\
\hline & DI water-SDS & -28.8 & 6.78 & - & - & - & - \\
\hline & XG-SDS & -53.8 & 7.04 & -46.4 & 6.87 & 7.41 & 8.15 \\
\hline \multirow[t]{3}{*}{$\mathrm{Al}_{2} \mathrm{O}_{3}$} & DI water & 16.4 & 6.75 & - & - & - & - \\
\hline & DI water-SDS & -26.9 & 6.54 & - & - & - & - \\
\hline & XG-SDS & -67.7 & 6.32 & -59.5 & 6.04 & 6.48 & 6.64 \\
\hline $\mathrm{Fe}(\mathrm{OH})_{3}$ & XG & - & - & - & - & 10.5 & 10.62 \\
\hline
\end{tabular}

\subsection{Viscosity Measurements}

The XG polymer solutions and nanopolymer sols exhibited shear-thinning behavior, which is attributed to the uncoiling and partial alignment of the XG chains at the high shear rate region (Figure 3a). The $4000 \mathrm{ppm} X \mathrm{X}$ solutions with $0.3 \mathrm{wt} \%$ and $1 \mathrm{wt} \%$ salt had slightly higher viscosity than the salt-free solution. This behavior was previously reported by Wyatt and Liberatore [13,52]. They found that, below a critical polymer concentration $\left(C_{c} \sim 2000 \mathrm{ppm}\right)$, the viscosity decreases upon addition of salt. The addition of counterions $\left(\mathrm{Na}^{+}\right)$contributes to neutralizing the electrostatic interactions between charges along the backbone of the XG chain, which allows the chain to fold, causing a reduction in the hydrodynamic size of the macromolecules. Since the XG chains decrease in size, the number of interactions with neighboring chains also decreases. For polymer concentrations $>C_{c}$, the interaction among the XG chains increases, and its effect on the viscosity of the solution becomes more important than the negative effect caused by the decrease in the hydrodynamic size of the macromolecules.

The addition of unmodified silica, $\mathrm{SiO}_{2}$-MPS, and $\mathrm{SiO}_{2}$-OTES NPs to the XG-SDS solutions has a positive effect on the viscosity values at all salt concentrations (Figure 3). For the salt-free nanopolymer sols, the increment in viscosity can be attributed to the interaction between -OH groups on the surface of the NPs (modified and unmodified) with the carboxylic groups on the trisaccharide side chains of the XG through hydrogen bonding [25] and hydrophobic interactions between the modifiers and the backbone of the polymer. Then, the unmodified and modified silica NPs act as physical crosslinker between polymer chains. When $\mathrm{NaCl}$ is added to these nanopolymer sols, the hydrophobic interactions between SDS micelles, NPs, and the XG chains increases, due to the screening of the electrostatic repulsion between them $[53,54]$. The repulsion forces between the attached SDS 
micelles and SDS-coated NPs will prevent the coiling of the XG chains, facilitating the formation of a tridimensional network with other NP-XG-SDS complexes, increasing the viscosity.

The reduction in viscosity of XG-SDS solution caused by the addition of $\mathrm{Fe}(\mathrm{OH})_{3}, \mathrm{Al}_{2} \mathrm{O}_{3}$, and $\mathrm{TiO}_{2}$ NPs suggests high adsorption of polymer molecules at the NP surface. High polymer adsorption on the NP surface reduces the viscosity of the polymer solution because it reduces the polymer concentration in the liquid phase and diminishes the bridging of polymer molecules with the NPs. The reduction in the polymer viscosity was observed at all salinities.
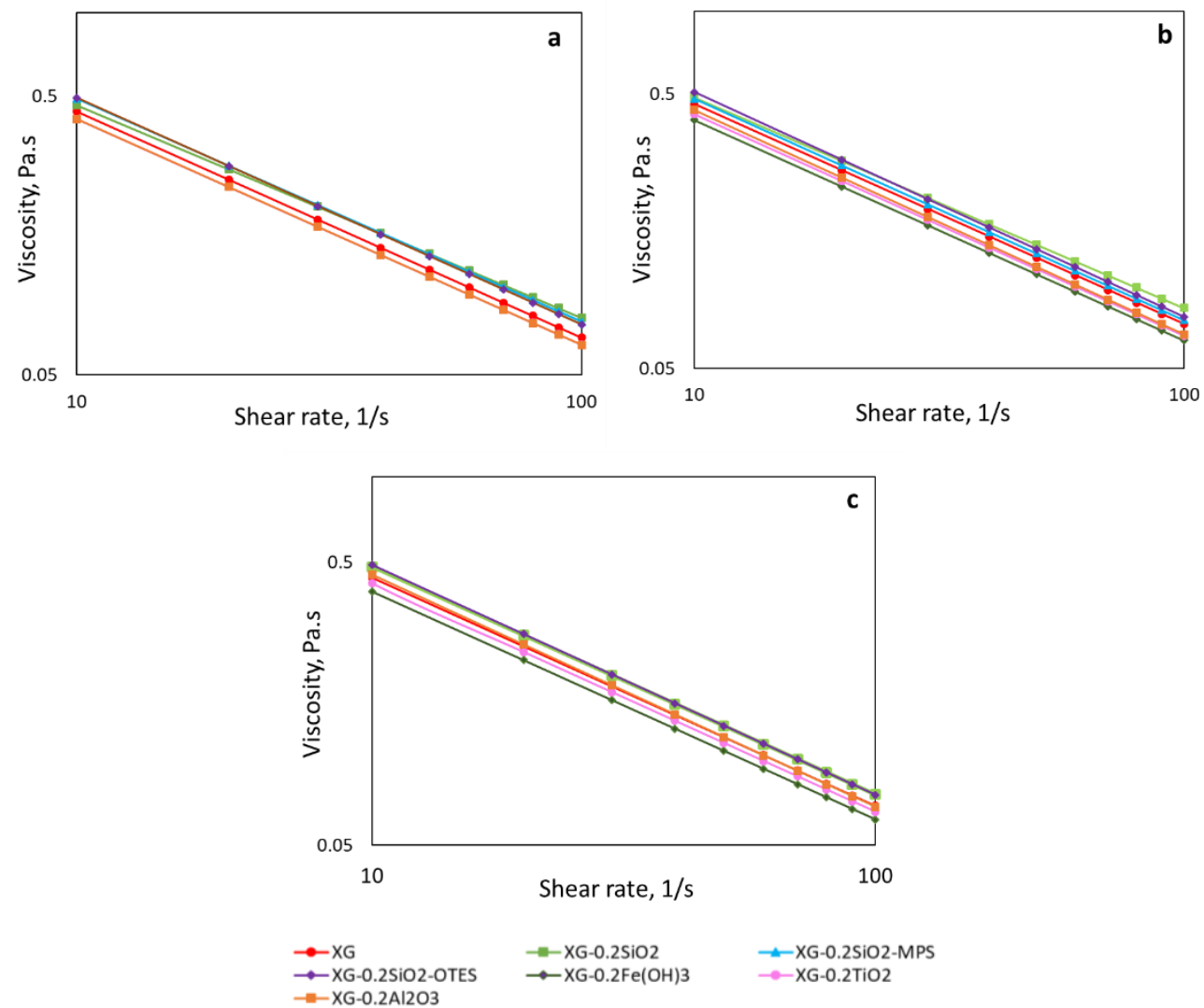

Figure 3. Viscosity of 4000 ppm XG solutions with 1000 ppm SDS and $\mathrm{SiO}_{2}, \mathrm{SiO}_{2}-\mathrm{MPS}, \mathrm{SiO}_{2}-\mathrm{OTES}$, $\mathrm{Al}_{2} \mathrm{O}_{3}, \mathrm{TiO}_{2}$, and $\mathrm{Fe}(\mathrm{OH})_{3}$ at a) 0 wt \%, (b) $0.3 \mathrm{wt} \%$, and (c) 1.0 wt $\% \mathrm{NaCl}$ concentration at $25{ }^{\circ} \mathrm{C}$.

The viscosity data of XG polymer solutions and nanopolymer sols exhibits a good fit to Ostwald-de Waele model (Equation 2). Nevertheless, a previous model developed by the authors [55] and based on multilayer perceptron (MLP) neural network can also be used for predicting the viscosity of nanopolymer sols. The rheological parameters ( $\mathrm{n}$ and $\mathrm{K}$ ) are presented in Table 2).

$$
\mu=K \cdot \dot{\gamma}^{n-1}
$$

where $\mathrm{n}$ is the flow index, dimensionless, and $K$ is the consistency factor, Pa. $\mathrm{s}^{\mathrm{n}}$. 
Table 2. Power law parameters for nanopolymer sols.

\begin{tabular}{|c|c|c|c|}
\hline Sample & K, Pa.s ${ }^{\mathrm{n}}$ & $\mathbf{n}$ & $r^{2}$ \\
\hline XG & 2.8601 & 0.188 & 0.9972 \\
\hline $\mathrm{XG}-0.3 \mathrm{NaCl}$ & 2.7642 & 0.199 & 0.9986 \\
\hline$X G-1.0 \mathrm{NaCl}$ & 2.8308 & 0.193 & 0.9982 \\
\hline $\mathrm{XG}-0.2 \mathrm{SiO}_{2}$ & 2.6939 & 0.237 & 0.9903 \\
\hline $\mathrm{XG}-0.2 \mathrm{SiO}_{2}-0.3 \mathrm{NaCl}$ & 2.8466 & 0.212 & 0.9989 \\
\hline$X \mathrm{G}-0.2 \mathrm{SiO}_{2}-1.0 \mathrm{NaCl}$ & 3.0761 & 0.195 & 0.9989 \\
\hline $\mathrm{XG}-0.2 \mathrm{SiO}_{2}-\mathrm{OTES}$ & 3.2163 & 0.186 & 0.9988 \\
\hline $\mathrm{XG}-0.2 \mathrm{SiO}_{2}-\mathrm{OTES}-0.3 \mathrm{NaCl}$ & 3.3465 & 0.181 & 0.9987 \\
\hline $\mathrm{XG}-0.2 \mathrm{SiO}_{2}-\mathrm{OTES}-1.0 \mathrm{NaCl}$ & 3.1808 & 0.187 & 0.9991 \\
\hline $\mathrm{XG}-0.2 \mathrm{SiO}_{2}-\mathrm{MPS}$ & 3.1175 & 0.198 & 0.9991 \\
\hline $\mathrm{XG}-0.2 \mathrm{SiO}_{2}-\mathrm{MPS}-0.3 \mathrm{NaCl}$ & 3.0886 & 0.193 & 0.9991 \\
\hline $\mathrm{XG}-0.2 \mathrm{SiO}_{2}-\mathrm{MPS}-1.0 \mathrm{NaCl}$ & 2.8506 & 0.186 & 0.9991 \\
\hline $\mathrm{XG}-0.2 \mathrm{Fe}(\mathrm{OH})_{3-}-0.3 \mathrm{NaCl}$ & 2.5509 & 0.197 & 0.9992 \\
\hline $\mathrm{XG}-0.2 \mathrm{Fe}(\mathrm{OH})_{3}-1.0 \mathrm{NaCl}$ & 2.5132 & 0.195 & 0.9992 \\
\hline $\mathrm{XG}-0.2 \mathrm{Al} 2 \mathrm{O}_{3}$ & 2.6541 & 0.189 & 0.9985 \\
\hline$X G-0.2 \mathrm{Al}^{2} \mathrm{O}_{3}-0.3 \mathrm{NaCl}$ & 2.8708 & 0.182 & 0.9989 \\
\hline $\mathrm{XG}-0.2 \mathrm{Al}_{2} \mathrm{O}_{3}-1.0 \mathrm{NaCl}$ & 2.9945 & 0.179 & 0.9989 \\
\hline $\mathrm{XG}-0.2 \mathrm{TiO}_{2}$ & 2.6801 & 0.19 & 0.9996 \\
\hline $\mathrm{XG}-0.2 \mathrm{TiO}_{2}-0.3 \mathrm{NaCl}$ & 2.7115 & 0.192 & 0.9993 \\
\hline $\mathrm{XG}-0.2 \mathrm{TiO}_{2}-1.0 \mathrm{NaCl}$ & 2.9036 & 0.232 & 0.9993 \\
\hline
\end{tabular}

\subsection{Displacement Test in Linear Sand-Pack}

Table 3 presents the absolute permeabilities and porosities of the sand-packs used in this study and Figure 4 shows the cumulative oil recovery curves for water, polymer, and nanopolymer sols floods. The $r^{2}$ values of the $\Delta P / \mathrm{L}$ vs. Q/A curves used to calculate the absolute permeabilities were between 0.9970 and 0.9999 . The cumulative oil recovery for waterflooding (WF) and polymer flooding was $38 \%$ and $67 \%$, respectively. The addition of NPs to the salt-free XG solution increased its cumulative oil recovery between 3\% and $9 \%$. The increment on oil recovery is attributed to the improvement of the injected fluid and oil mobility ratio. The highest oil recovery was obtained with MPS- and OTES-modified $\mathrm{SiO}_{2} \mathrm{NPs}$.

At $0.3 \mathrm{wt} \% \mathrm{NaCl}, \mathrm{NPs}$ increased the cumulative oil recovery between $1 \%$ and $5 \%$, except for $\mathrm{SiO}_{2}$-MPS. The oil recovery of $\mathrm{SiO}_{2}$-MPS was $2 \%$ lower than that of the XG solution. The reduction of the incremental oil recovery showed by all NPs can be attributed to NP and polymer adsorption on the sand grains induced by the addition of $\mathrm{NaCl}$. Since the nanopolymer sols have a $\mathrm{pH}$ higher than 2 (between 6.04 and 10.62), the sand grain surface is likely negatively charged. Then, the formation and adsorption of NPs aggregates, and the adsorption of XG chains on the surface of the sand grains $[56,57]$ is promoted by the counterions $\left(\mathrm{Na}^{+}\right)$. The $\Delta P$ values during nanopolymer flooding increased as salinity increased, due to the permeability reduction caused by the adsorption of NPs aggregates and $X G$ chains within the porous medium (Table 3). The highest $\Delta P$ value during nanopolymer flooding was obtained by the injection of $\mathrm{SiO}_{2}$-MPS nanopolymer sol, which is in agreement with its low cumulative oil recovery. The highest oil recovery was obtained with $\mathrm{SiO}_{2}$-OTES NPs, which showed higher increment on $X G$ viscosity and lower $\Delta P$ values. 
Table 3. Properties of the sand-pack and $\Delta P$ after water and polymer flooding.

\begin{tabular}{|c|c|c|c|c|}
\hline Experiment & $K_{a b s}, \mathrm{D}$ & $\Phi$ & $\begin{array}{c}\Delta P \text { after Polymer Flooding, } \\
\mathrm{psi} / \mathrm{ft}\end{array}$ & $\begin{array}{c}\Delta P \text { after Waterflooding, } \\
\mathrm{psi} / \mathrm{ft}\end{array}$ \\
\hline Water & 6.25 & 0.35 & - & 1.9 \\
\hline XG & 5.93 & 0.31 & 8.2 & 4.5 \\
\hline $\mathrm{XG}-0.3 \mathrm{NaCl}$ & 6.49 & 0.34 & 35.7 & 5.0 \\
\hline XG-1.0NaCl & 5.99 & 0.34 & 120.0 & 10.1 \\
\hline$X \mathrm{G}-0.2 \mathrm{SiO}_{2}$ & 5.65 & 0.33 & 156.0 & 17.4 \\
\hline $\mathrm{XG}-0.2 \mathrm{SiO}_{2}-0.3 \mathrm{NaCl}$ & 5.96 & 0.34 & 161.0 & 25.4 \\
\hline$X \mathrm{G}-0.2 \mathrm{SiO}_{2}-1.0 \mathrm{NaCl}$ & 6.56 & 0.36 & 202.0 & 35.2 \\
\hline XG-0.2SiO $2-\mathrm{OTES}$ & 6.09 & 0.35 & 82.0 & 26.0 \\
\hline $\mathrm{XG}-0.2 \mathrm{SiO}_{2}-\mathrm{OTES}-0.3 \mathrm{NaCl}$ & 6.66 & 0.36 & 92.0 & 30.6 \\
\hline $\mathrm{XG}-0.2 \mathrm{SiO}_{2}-\mathrm{OTES}-1.0 \mathrm{NaCl}$ & 5.64 & 0.34 & 185.0 & 32.0 \\
\hline XG-0.2SiO $2-\mathrm{MPS}$ & 5.78 & 0.33 & 98.0 & 22.0 \\
\hline $\mathrm{XG}-0.2 \mathrm{SiO}_{2}-\mathrm{MPS}-0.3 \mathrm{NaCl}$ & 6.49 & 0.36 & 173.0 & 43.4 \\
\hline $\mathrm{XG}-0.2 \mathrm{SiO}_{2}-\mathrm{MPS}-1.0 \mathrm{NaCl}$ & 6.06 & 0.35 & 196.0 & 57.0 \\
\hline $\mathrm{XG}-0.2 \mathrm{Al}_{2} \mathrm{O}_{3}$ & 6.16 & 0.35 & 127.5 & 40.0 \\
\hline $\mathrm{XG}-0.2 \mathrm{Al}_{2} \mathrm{O}_{3}-0.3 \mathrm{NaCl}$ & 6.52 & 0.35 & 136.1 & 53.5 \\
\hline$X \mathrm{XG}-0.2 \mathrm{Al}_{2} \mathrm{O}_{3}-1.0 \mathrm{NaCl}$ & 6.77 & 0.37 & 230.9 & 65.9 \\
\hline $\mathrm{XG}-0.2 \mathrm{TiO}_{2}$ & 5.96 & 0.32 & 56.0 & 24.0 \\
\hline $\mathrm{XG}-0.2 \mathrm{TiO}_{2}-0.3 \mathrm{NaCl}$ & 6.02 & 0.33 & 99.0 & 27.1 \\
\hline $\mathrm{XG}-0.2 \mathrm{TiO}_{2}-1.0 \mathrm{NaCl}$ & 6.67 & 0.36 & 136.9 & 37.5 \\
\hline $\mathrm{XG}-0.2 \mathrm{Fe}(\mathrm{OH})_{3}-0.3 \mathrm{NaCl}$ & 5.78 & 0.31 & 150.0 & 65.0 \\
\hline $\mathrm{XG}-0.2 \mathrm{Fe}(\mathrm{OH})_{3}-1.0 \mathrm{NaCl}$ & 5.94 & 0.32 & 154.0 & 88.0 \\
\hline
\end{tabular}
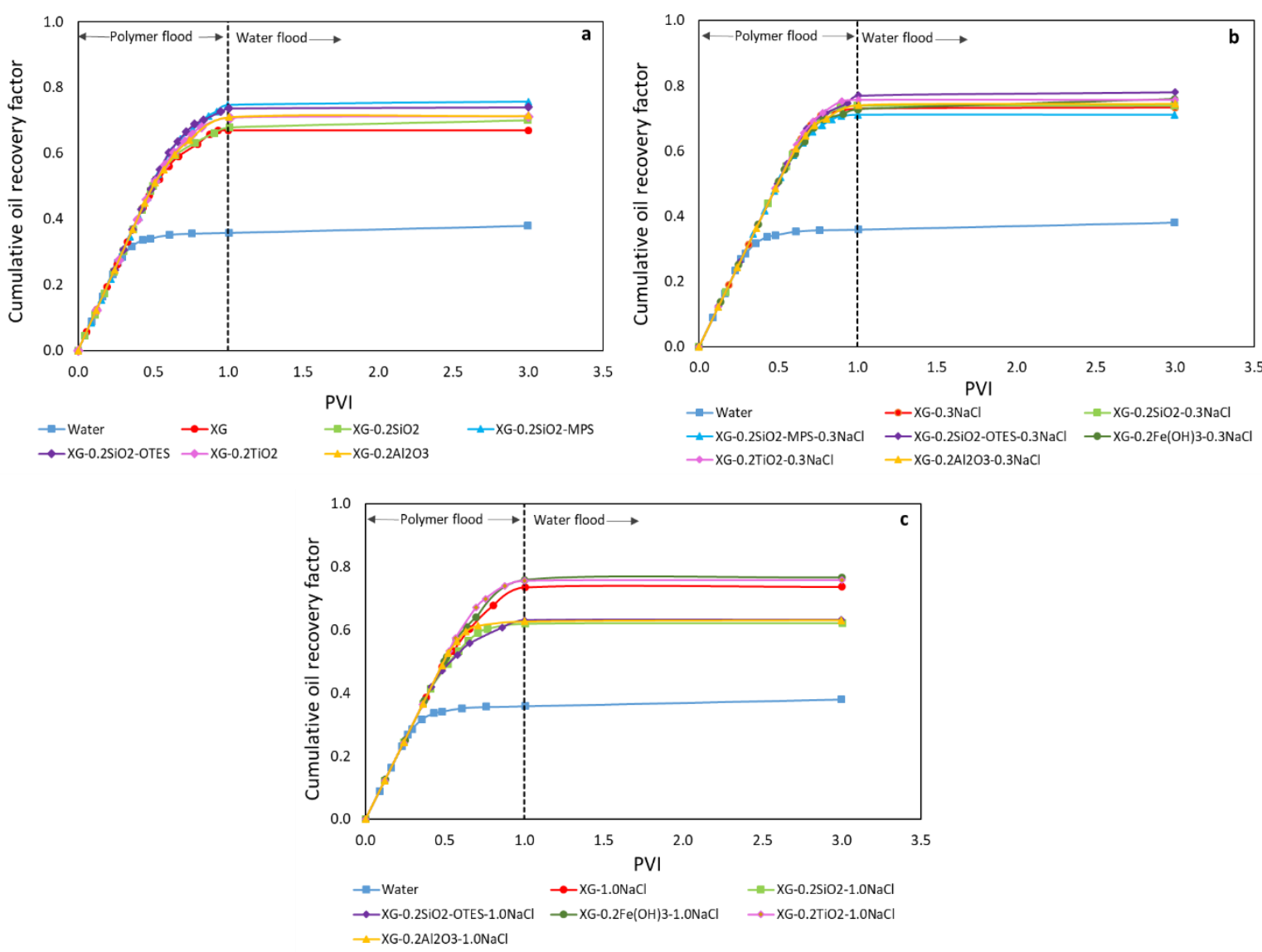

Figure 4. Cumulative oil recovery of $4000 \mathrm{ppm} X \mathrm{XG}$ solutions with $1000 \mathrm{ppm}$ SDS and $\mathrm{SiO}_{2}, \mathrm{SiO}_{2}-\mathrm{MPS}$, $\mathrm{SiO}_{2}$-OTES, $\mathrm{Al}_{2} \mathrm{O}_{3}, \mathrm{TiO}_{2}$, and $\mathrm{Fe}(\mathrm{OH})_{3}$ at a) 0 wt \%, (b) $0.3 \mathrm{wt} \%$, and (c) 1.0 wt $\% \mathrm{NaCl}$ concentration at $25^{\circ} \mathrm{C}$. 
At $1.0 \mathrm{wt} \% \mathrm{NaCl}$, the addition unmodified $\mathrm{SiO}_{2}, \mathrm{SiO}_{2}-\mathrm{MPS}, \mathrm{SiO}_{2}-\mathrm{OTES}$, and $\mathrm{Al}_{2} \mathrm{O}_{3}$ reduced the cumulative oil recovery between $5 \%$ and $12 \%$. However, the addition of $\mathrm{Fe}(\mathrm{OH})_{3}$ and $\mathrm{TiO}_{2}$ NPs increased the cumulative oil recovery between $2 \%$ and $3 \%$. The performance of the $\mathrm{Fe}(\mathrm{OH})_{3}$ and $\mathrm{TiO}_{2}$ NPs can be attributed to lower polymer adsorption on the surface of the sand grains. The alkaline nature of both nanopolymer sols $\left(\mathrm{Fe}(\mathrm{OH})_{3} \mathrm{pH}=10.62\right.$, and $\left.\mathrm{TiO}_{2} \mathrm{pH}=8.15\right)$ increases the negative charge density of the sand grains [57] and the negative charges on the XG chains through the deprotonation of the carboxylic acids [12], thus, the repulsive forces between the XG chains and the sand grains increases, which leads to lower adsorption of the polymer. The high $\Delta \mathrm{P}$ values during the injection of $\mathrm{Fe}(\mathrm{OH})_{3}$ and $\mathrm{TiO}_{2}$ nanopolymer sols are related mainly to the adsorption of NPs aggregates on the sand grains. In general, $\mathrm{Fe}(\mathrm{OH})_{3}$ and $\mathrm{TiO}_{2}$ nanopolymer sols were the only nanopolymer sols that show the same incremental oil recovery at $0.3 \mathrm{wt} \%$ and $1.0 \mathrm{wt} \% \mathrm{NaCl}$. It seems that the increment of the repulsive forces between the XG chains and the sand grains can mitigate the negative effect caused by the NP adsorption on the sand grains.

\section{Conclusions}

In this study, formulation and characterization of nanopolymer sols of XG with hydrophobic and hydrophilic metal oxide NPs is reported. The properties of the nanopolymer sols were explored using $\zeta$-potential and viscosimetry. The performance of all nanopolymer sols was evaluated by conducting heavy oil recovery tests in linear sand-packs. The role of the physical and chemical interactions between NPs and XG solutions, and the relationship between their hybrid structure, properties, and their performance were investigated.

The colloidal stability of the NPs dispersed in DI water and XG solution was evaluated by the $\zeta$-potential measurements. The NP dispersions in deionized (DI) water exhibited low $\zeta$-potential values, which suggested low dispersion stability. Nevertheless, the addition of XG induced steric stabilization. It was observed that the addition of untreated silica, $\mathrm{SiO}_{2}-\mathrm{MPS}$, and $\mathrm{SiO}_{2}-\mathrm{OTES} \mathrm{NPs}$ improved the thickening behavior of the $\mathrm{XG}$ solution. However, $\mathrm{Fe}(\mathrm{OH})_{3}, \mathrm{Al}_{2} \mathrm{O}_{3}$, and $\mathrm{TiO}_{2} \mathrm{NPs}$ decreased the viscosity of the polymer solution. The displacement tests showed that the breakthrough time occurred later with the injection of the nanopolymer sols, since the reduction of mobility ratio increased the macroscopic efficiency. At $0 \mathrm{wt} \%$ and $0.3 \mathrm{wt} \% \mathrm{NaCl}$, the addition of NPs increased the cumulative oil recovery between $3 \%$ and $9 \%$, and between $1 \%$ and $5 \%$, respectively. At $1.0 \mathrm{wt} \% \mathrm{NaCl}$, unmodified $\mathrm{SiO}_{2}, \mathrm{SiO}_{2}$-MPS, $\mathrm{SiO}_{2}$-OTES, and $\mathrm{Al}_{2} \mathrm{O}_{3}$ reduced the cumulative oil recovery between $5 \%$ and $12 \%$, whereas $\mathrm{Fe}(\mathrm{OH})_{3}$ and $\mathrm{TiO}_{2} \mathrm{NPs}$ increased it between $2 \%$ and $3 \%$.

Supplementary Materials: The following are available online at http:/ /www.mdpi.com/2079-4991/9/1/94/s1, Table S1: Average particle size measurement using DLS.

Author Contributions: Conceptualization, L.M.C., M.M.H. and B.B.M.; Formal analysis, L.M.C.; Investigation, L.M.C. Methodology, L.M.C., M.M.H. and B.B.M.; Resources, B.B.M.; Supervision, M.M.H. and B.B.M.; Validation, M.M.H. and B.B.M.; Writing—original draft, L.M.C.; Writing—review \& editing, M.M.H. and B.B.M.

Funding: This research received no external funding.

Acknowledgments: Laura M. Corredor gratefully acknowledges Ecopetrol S.A for the scholarship to pursue her graduate studies, and Bernie Then, Amitabha Majumdar and Ola Jabar for their technical assistance.

Conflicts of Interest: The authors declare no conflict of interest.

\section{Abbreviations}

The following abbreviations are used in this manuscript:

A

$\mathrm{D}$ cross-sectional area of the pack

$\mathrm{FeCl}_{3} \cdot 6 \mathrm{H}_{2} \mathrm{O}$ iron(III) chloride hexahydrate

HPAM hydrolyzed polyacrylamide

IFT interfacial tension 


\begin{tabular}{|c|c|}
\hline K & permeability \\
\hline$K_{a b s}$ & absolute permeability \\
\hline K & consistency factor \\
\hline $\mathrm{KBr}$ & potassium bromide \\
\hline$L$ & length of the pack \\
\hline MW & molecular weight \\
\hline $\mathrm{n}$ & flow index \\
\hline PV & pore volume \\
\hline PVI & pore volume injected \\
\hline$Q$ & volumetric flow rate \\
\hline SDS & sodium dodecyl sulfate \\
\hline $\mathrm{SiO}_{2}$-MPS & silica modified with 3-(methacryloyloxy)propyl]trimethoxysilane \\
\hline $\mathrm{SiO}_{2}$-OTES & silica modified with octyltriethoxysilane \\
\hline WF & waterflooding \\
\hline XG & xanthan gum \\
\hline$\Delta P$ & differential pressure across the sand-pack \\
\hline$\Phi$ & porosity \\
\hline$\dot{\gamma}$ & shear rate \\
\hline$\mu$ & viscosity of water \\
\hline
\end{tabular}

\section{References}

1. Lutchmansingh, P.M.; Marietta, C.; Ertekin, T.; Abou-Kassem, J.H. Quantitative Analysis of Performance of Polymer Slug Injection. In Proceedings of the SPE Eastern Regional Meeting, Charleston, WV, USA, 1-4 November 1988; pp. 125-131. Available online: http:// search.ebscohost.com/login.aspx?direct=true\&db= pta\&AN=451379\&site=ehost-live (accessed on 15 September 2018).

2. Sheng, J.J.; Leonhardt, B.; Azri, N. Status of Polymer-Flooding Technology. J. Can. Pet. Technol. 2015, 54, 116-126. [CrossRef]

3. Kamal, M.S.; Sultan, A.S.; Al-Mubaiyedh, U.A.; Hussein, I.A. Review on Polymer Flooding: Rheology, Adsorption, Stability, and Field Applications of Various Polymer Systems. Polym. Rev. 2015, 55, 491-530. [CrossRef]

4. Zhang, X.; Liu, X.; Gu, D.; Zhou, W.; Xie, T.; Mo, Y. Rheological models for xanthan gum. J. Food Eng. 1996, 27, 203-209. [CrossRef]

5. Pelletier, E.; Viebke, C.; Meadows, J.; Williams, P.A. A Rheological Study of the Order-Disorder Conformational Transition of xanthan gum. Biopolymers 2001, 59, 339-346. [CrossRef]

6. Xu, L.; Dong, M.; Gong, H.; Sun, M.; Li, Y. Effects of inorganic cations on the rheology of aqueous welan, xanthan, gellan solutions and their mixtures. Carbohydr. Polym. 2015, 121, 147-154. [CrossRef] [PubMed]

7. Xu, L.; Xu, G.; Liu, T.; Chen, Y.; Gong, H. The comparison of rheological properties of aqueous welan gum and xanthan gum solutions. Carbohydr. Polym. 2013, 92, 516-522. [CrossRef] [PubMed]

8. Jang, H.Y.; Zhang, K.; Chon, B.H.; Choi, H.J. Enhanced oil recovery performance and viscosity characteristics of polysaccharide xanthan gum solution. J. Ind. Eng. Chem. 2015, 21, 741-745. [CrossRef]

9. Ghoumrassi-Barr, S.; Aliouche, D. A Rheological Study of Xanthan Polymer for Enhanced Oil Recovery. J. Macromol. Sci. Part B 2016, 55, 793-809. [CrossRef]

10. Milas, M.; Rinaudo, M. Conformational investigation on the bacterial polysaccharide xanthan. Carbohydr. Res. 1979, 76, 189-196. [CrossRef]

11. Lambert, F.; Rinaudo, M. On the thermal stability of xanthan gum. Polymer 1985, 26, 1549-1553. [CrossRef]

12. Brunchi, C.-E.; Bercea, M.; Morariu, S.; Dascalu, M. Some properties of xanthan gum in aqueous solutions: Effect of temperature and pH. J. Polym. Res. 2016, 23, 123. [CrossRef]

13. Wyatt, N.B.; Liberatore, M.W. The effect of counterion size and valency on the increase in viscosity in polyelectrolyte solutions. Soft Matter 2010, 6, 3346-3352. [CrossRef]

14. Zhong, L.; Oostrom, M.; Truex, M.J.; Vermeul, V.R.; Szecsody, J.E. Rheological behavior of xanthan gum solution related to shear thinning fluid delivery for subsurface remediation. J. Hazard. Mater. 2013, 244-245, 160-170. [CrossRef] [PubMed] 
15. Smith, I.H.; Symes, K.C.; Lawson, C.J.; Morris, E.R. Influence of the pyruvate content of xanthan on macromolecular association in solution. Int. J. Biol. Macromol. 1981, 3, 129-134. [CrossRef]

16. Wellington, S. Biopolymer Solution Viscosity Stabilization-Polymer Degradation and Antioxidant Use. Soc. Pet. Eng. J. 1983, 23, 901-912. [CrossRef]

17. Ryles, R.G. Chemical Stability Limits of Water-Soluble Polymers Used in Oil Recovery Processes. SPE Reserv. Eng. 1988, 3, 23-34. [CrossRef]

18. Seright, R.S.; Henrici, B.J. Xanthan Stability at Elevated Temperatures. SPE Reserv. Eng. 1990, 5, 52-60. [CrossRef]

19. Hamedi Shokrlu, Y.; Babadagli, T. Transportation and interaction of nano and micro size metal particles injected to improve thermal recovery of heavy-oil. In Proceedings of the SPE Annual Technical Conference and Exhibition, Denver, CO, USA, 30 October-2 November 2011; Volume 3, pp. 2257-2268. [CrossRef]

20. Ponmani, S.; William, J.K.; Samuel, R.; Nagarajan, R.; Sangwai, J.S. Formation and characterization of thermal and electrical properties of $\mathrm{CuO}$ and $\mathrm{ZnO}$ nanofluids in xanthan gum. Colloids Surf. A Physicochem. Eng. Aspects 2014, 443, 37-43. [CrossRef]

21. William, J.K.; Ponmani, S.; Samuel, R.; Nagarajan, R.; Sangwai, J.S. Effect of CuO and ZnO nanofluids in xanthan gum on thermal, electrical and high-pressure rheology of water-based drilling fluids. J. Pet. Sci. Eng. 2014, 117, 15-27. [CrossRef]

22. Comba, S.; Dalmazzo, D.; Santagata, E.; Sethi, R. Rheological characterization of xanthan suspensions of nanoscale iron for injection in porous media. J. Hazard. Mater. 2011, 185, 598-605. [CrossRef]

23. Xue, D.; Sethi, R. Viscoelastic gels of guar and xanthan gum mixtures provide long-term stabilization of iron micro- and nanoparticles. J. Nanopart. Res. 2012, 14, 1-14. [CrossRef]

24. Attia, A.M.; Musa, H. Effect of Sodium Magnesium Silicate Nanoparticles on Rheology of Xanthan Gum Polymer. Int. J. Sci. Eng. Res. 2015, 6, 1349-1364.

25. Kennedy, J.; Kent, K.; Brown, J. Rheology of dispersions of xanthan gum, locust bean gum and mixed biopolymer gel with silicon dioxide nanoparticles. Mater. Sci. Eng. C 2015, 48, 347-353. [CrossRef] [PubMed]

26. Yang-Chuan, K.; Guang-Yao, W.; Yi, W. Preparation, morphology and properties of nanocomposites of polyacrylamide copolymers with monodisperse silica. Eur. Polym. J. 2008, 44, 2448-2457. [CrossRef]

27. Maghzi, A.; Mohebbi, A.; Kharrat, R.; Ghazanfari, M.H. An experimental investigation of silica nanoparticles effect on the rheological behavior of polyacrylamide solution to enhance heavy oil recovery. Pet. Sci. Technol. 2013, 31, 500-508. [CrossRef]

28. Maghzi, A.; Kharrat, R.; Mohebbi, A.; Ghazanfari, M.H. The impact of silica nanoparticles on the performance of polymer solution in presence of salts in polymer flooding for heavy oil recovery. Fuel 2014, 123, 123-132. [CrossRef]

29. Zeyghami, M.; Kharrat, R.; Ghazanfari, M.H. Investigation of the Applicability of Nano Silica Particles as a Thickening Additive for Polymer Solution Applied in EOR Processes. Energy Sources Part A 2014, 36, 1315-1324. [CrossRef]

30. Zhu, D.; Han, Y.; Zhang, J.; Li, X.; Feng, Y. Enhancing rheological properties of hydrophobically associative polyacrylamide aqueous solutions by hybriding with silica nanoparticles. J. Appl. Polym. Sci. 2014, 131, 1-8. [CrossRef]

31. Yousefvand, H.; Jafari, A. Enhanced Oil Recovery Using Polymer/nanosilica. Procedia Mater. Sci. 2015, 11, 565-570. [CrossRef]

32. Maurya, N.K.; Mandal, A. Studies on behavior of suspension of silica nanoparticle in aqueous polyacrylamide solution for application in enhanced oil recovery. Pet. Sci. Technol. 2016, 34, 429-436. [CrossRef]

33. Cheraghian, G. Application of nano-fumed silica in heavy oil recovery. Pet. Sci. Technol. 2016, 34, 12-18. [CrossRef]

34. Sharma, T.; Iglauer, S.; Sangwai, J.S. Silica Nanofluids in an Oilfield Polymer Polyacrylamide: Interfacial Properties, Wettability Alteration, and Applications for Chemical Enhanced Oil Recovery. Ind. Eng. Chem. Res. 2016, 55, 12387-12397. [CrossRef]

35. Sharma, T.; Sangwai, J.S. Silica nanofluids in polyacrylamide with and without surfactant: Viscosity, surface tension, and interfacial tension with liquid paraffin. J. Pet. Sci. Eng. 2017. [CrossRef]

36. Saha, R.; Uppaluri RV, S.; Tiwari, P. Silica Nanoparticle Assisted Polymer Flooding of Heavy Crude Oil: Emulsification, Rheology, and Wettability Alteration Characteristics. Ind. Eng. Chem. Res. 2018, 57, 6364-6376. [CrossRef] 
37. Ogolo, N.A.; Olafuyi, O.A.; Onyekonwu, M.O. SPE 160847. Enhanced Oil Recovery Using Nanoparticles. In Proceedings of the SPE Technical Symposium and Exhibition, Al-Khobar, SAU, 8-11 April 2012; pp. 1-9. [CrossRef]

38. Hendraningrat, L.; Torsæter, O. Metal oxide-based nanoparticles: revealing their potential to enhance oil recovery in different wettability systems. Appl. Nanosci. 2014, 5, 181-199. [CrossRef]

39. Ehtesabi, H.; Ahadian, M.M.; Taghikhani, V. Enhanced Heavy Oil Recovery Using $\mathrm{TiO}_{2}$ Nanoparticles: Investigation of Deposition during Transport in Core Plug. Energy Fuels 2015, 29, 1-8. [CrossRef]

40. Negin, C.; Ali, S.; Xie, Q. Application of nanotechnology for enhancing oil recovery-A review. Petroleum 2016, 2, 324-333. [CrossRef]

41. Sondi, I.; Fedynyshyn, T.H.; Sinta, R.; Matijević, E. Encapsulation of nanosized silica by in situ polymerization of tert-butyl acrylate monomer. Langmuir 2000, 16, 9031-9034. [CrossRef]

42. Al-Oweini, R.; El-Rassy, H. Synthesis and characterization by FTIR spectroscopy of silica aerogels prepared using several $\mathrm{Si}(\mathrm{OR})_{4}$ and $\mathrm{R}^{\prime \prime} \mathrm{Si}\left(\mathrm{OR}^{\prime}\right)_{3}$ precursors. J. Mol. Struct. 2009, 919, 140-145. [CrossRef]

43. Moral, L.M. Development of Functionalized Aerogels for Applications as Catalyst and Hydrides Matrix. Ph.D. Thesis, Universidad de Valladolid, Valladolid, Spain, 2016.

44. Zhuravlev, L.T. The surface chemistry of amorphous silica. Zhuravlev model. Colloids Surf. A Physicochem. Eng. Aspects 2000, 173, 1-38. [CrossRef]

45. American Society for Testing and Materials. Methods of Test for Zeta Potential of Colloids in Water and Waste Water; ASTM D4187-82; American Society for Testing and Materials: West Conshohocken, PA, USA, 1985.

46. Gun'ko, V.M.; Zarko, V.I.; Leboda, R.; Chibowski, E. Aqueous suspension of fumed oxides: Particle size distribution and zeta potential. Adv. Colloid Interface Sci. 2001, 91, 1-112. [CrossRef]

47. Colic, M.; Fisher, M.L.; Franks, G.V. Influence of Ion Size on Short-Range Repulsive Forces between Silica Surfaces. Langmuir 1998, 14, 6107-6112. [CrossRef]

48. Singh, B.P.; Menchavez, R.; Takai, C.; Fuji, M.; Takahashi, M. Stability of dispersions of colloidal alumina particles in aqueous suspensions. J. Colloid Interface Sci. 2005, 291, 181-186. [CrossRef] [PubMed]

49. Husein, M. Preparation of nanoscale organosols and hydrosols via the phase transfer route. J. Nanopart. Res. 2017, 19. [CrossRef]

50. Somasundaran, P.; Fuerstenau, D.W. Mechanisms of Alkyl Sulfonate Adsorption at the Alumina-Water Interface 1. J. Phys. Chem. 1966, 70, 90-96. [CrossRef]

51. Pomogailo, A.D.; Kestelman, V.N. Metallopolymer Nanocomposites; Springer: Berlin/Heidelberg, Germany, 2005.

52. Wyatt, N.B.; Liberatore, M.W. Rheology and Viscosity Scaling of the Polyelectrolyte Xanthan Gum. J. Appl. Polym. Sci. 2009, 114, 4076-4084. [CrossRef]

53. Khan, M.Y.; Samanta, A.; Ojha, K.; Mandal, A. Interaction between aqueous solutions of polymer and surfactant and its effect on physicochemical properties. Asia-Pac. J. Chem. Eng. 2008, 3, 579-585. [CrossRef]

54. Nedjhioui, M.; Moulai-Mostefa, N.; Canselier, J.P.; Bensmaili, A. Investigation of combined effects of xanthan gum, sodium dodecyl sulphate, and salt on some physicochemical properties of their mixtures using a response surface method. J. Dispers. Sci. Technol. 2009, 30, 1333-1341. [CrossRef]

55. Corredor-Rojas, L.M.; Hemmati-Sarapardeh, A.; Husein, M.M.; Dong, M.; Maini, B.B. Rheological Behavior of Surface Modified Silica Nanoparticles Dispersed in Partially Hydrolyzed Polyacrylamide and Xanthan Gum Solutions: Experimental Measurements, Mechanistic Understanding, and Model Development. Energy Fuels 2018. [CrossRef]

56. Caldelas, F.; Murphy, M.J.; Huh, C.; Bryant, S.L. SPE 142305 Factors Governing Distance of Nanoparticle Propagation in Porous Media. In Proceedings of the SPE Production \& Operations Symposium, Oklahoma City, OK, USA, 27-29 March 2011; pp. 1-16. [CrossRef]

57. Mishra, S.; Bera, A.; Mandal, A.; Mishra, S.; Bera, A.; Mandal, A. Effect of Polymer Adsorption on Permeability Reduction in Enhanced Oil Recovery. J. Pet. Eng. 2014, 2014, 1-9. [CrossRef]

(C) 2019 by the authors. Licensee MDPI, Basel, Switzerland. This article is an open access article distributed under the terms and conditions of the Creative Commons Attribution (CC BY) license (http:/ / creativecommons.org/licenses/by/4.0/). 